\title{
The Analysis of Determining Cost of Products and the Application of Cost Plus Price Methods in Ordering Natural Gas Sell Prices in the Gundih Area of PT Pertamina Asset EP 4 Field Cepu, in Sumber Village, Kradenan Sub-District, Blora District
}

\author{
Yunanik $^{1, *}$ Andian Ari Istiningrum ${ }^{2}$ Tri Warcono Adi $^{3}$ \\ 1,2,3 Logistics of Oil and Gas Department Energy and Mineral Polytechnic (PEM AKAMIGAS) Cepu, Indonesia \\ ${ }^{*}$ Corresponding author. Email: yunanikyuna63@gmail.com
}

\begin{abstract}
This study was to determine the determination of the Cost of Goods Sold for natural gas produced by the Central Processing Plant in Blora District. Total production of natural gas distribution in 2019 through the Natural Gas Distribution Network is 2.36 MMCFD. The cost of natural gas products which has a value is Rp. 3,333/M3, 4000/M3, and the determination of the cost of gas based on recalculation by researchers, the natural gas that can be produced by the Central Processing Plant scenario I is IDR 5,771/M3 and the calculation of COGS according to the regulations to the calculation of the researcher results in a higher cost of goods. Selling prices according to the company and the Cost Plus Pricing Method per $1 \mathrm{M} 3$ of natural gas in scenario I is Rp. 6,638/M3.
\end{abstract}

Keywords: Cost of Goods Sol, Natural Gas.

\section{INTRODUCTION}

In 2018, a research was carried out with the theme Market Potential Mapping in the framework of a Feasibility Study on Utilizing the Balun Field Gas Well, and the results of the Benefit Cost Ratio (BCR) analysis obtained a value of $\mathrm{B} / \mathrm{C}=0.9022(<1)$ which indicates that economically the utilization project The Balun Field gas well is not feasible, however, it is an effort to contribute to the development of the education sector / as a learning tool at PEM Akamigas. Furthermore, based on the policy of the leadership, a feasibility study research was carried out in the Semanggi production field which has an area of $+4,000$ hectares. Semanggi is for the development of the education sector/as a learning tool at PEM Akamigas as well as the Micro Industry later. Semanggi has an area $+4,000$ hectares. The main occupation of the majority of farmers is that forest products in the village can contribute to regional income +500 million. Production from the Semanggi Field is channeled to the Mini Plant to separate oil and gas. Gas is used for power generation, while the oil production is sent by line to the main collection station (SPU). Then produced to the Main Gathering Station (MGS) and in the
Semanggi area, the gas produced is around 1,035 million standard cubic feet per day (MMSCFD) for gas.

Semanggi is directly adjacent to a wealth of natural resources, but the gas produced is still unable to flow the area itself, because the gas source gas is only used for the gas engine. In connection with this, the authors conducted research on the Gundih Area of PT Pertamina Asset EP 4 Field Cepu, in Sumber Village, Kradenan District, Blora, together with the government's program for the gas network in Blora Regency, which is targeted as natural gas users in 2020, is 4000 House Connections (SR). Utilization of gas wells that are planned for the prosperity of the people must be able to provide the greatest possible benefit to the community, either directly or indirectly. Furthermore, the use of natural gas at affordable prices throughout Blora Regency. The amount of the cost of making a product in accounting terms is known as the Cost of Product (COGS). There are two possibilities that will be encountered if the company is not careful in calculating the cost of goods, namely: [1]. Prices that are calculated to be too high, will cause problems for the company, because high cost of goods can cause the selling price of products in the market to be 
expensive [2]. the cost of goods that is calculated to be too low, causing the cost of goods to be too low can harm the company itself. Full costing and variable costing are methods of determining the cost of goods manufactured. Analysis of Cost of Production (COGS) information which will be a reference for companies in determining the selling price of natural gas products, with gas production of 65 million cubic feet per day (mmscfd)

In 2013, it has reached 11 sectors with a total connection of 4,000 SRs, sector I consists of 817 SRs, but those that have been active have only reached 641 SRs and the rest have not been flowed. While 10 sectors have not been supplied and the infrastructure / gas network has been installed due to problems with moving houses, buildings automatically moved because the village community generally houses made of wood, licensing problems from PT KAI. Based on the foregoing, the writer will analyze how to determine the COGS for the selling price of natural gas, for that the writer takes the theme: "Analysis of Determination of Cost of Products and Application of Cost Plus Pricing Method in Determining the Selling Price of Natural Gas in the Gundih Area of PT Pertamina Asset EP. 4 Field Cepu In Sumber Village Kradenan District, Blora Regency”

The main problem in this research is related to the utilization of natural gas in the Gundih Area, in the Village of Sumber Kradenan District, and is a research in determining the cost of sales of natural gas products from the Gundih Area, Sumber Village, Kradenan District, this problem is still relevant to be studied through various kinds. Policies include calculating the COGS of a production business using the steps above, both for home-scale production businesses and not. To find out whether the selling price we have applied is correct or not, we must first determine the cost of goods or calculate the correct and rational COGS. Determination of the correct cost of product is very important for the company in running its business. Incorrect product designation will cause the company to fail in its line of business.

\section{METHOD}

The method used are quantitative descriptive and comparative approach by comparing the method used by the company with the full costing method in calculating or determining the cost of goods manufactured. While the cost plus pricing method will be used to determine the selling price of the product and then compare it with the method used by the company, with the following stages:

1. Literature study of the patterns used by companies with the full costing method in calculating or determining the cost of goods manufactured with related functions

2. Consultation with experts/practitioners from PT Pertamina Asset 4, Sumber Village Officials and Blora Regency government officials,
3. Restricting the problem:

a. Calculation of the cost of product (COGS), namely the cost of gas energy products originating from the research area and the cost of the proposed natural gas products.

b. The calculation of the simultaneous use of each appliance in one day is 8 hours, where the assumption used is the amount of cooking usage in 1 day is 3 hours

c. The calculation of COGS in 2 scenarios, namely 5 years and 10 years.

d. Do not include tax calculations in calculating COGS.

e. Does not include the calculation of activities other than production in calculating the cost of goods in the current system.

f. The rate of return on capital with the interest rate used in the calculation is $5.3 \%$, with inflation of $3.5 \%$ (Basic Assumptions for the 2019 State Budget Macoreconomics)

4. Recommendations for improving the quality of the implementation of activities related to determining COGS in the context of utilizing natural gas wells, material for consideration and program actions and synergies.

5. Compilation of reports on current price conditions.

\section{RESULT AND DISCUSSION}

Mojorembun, Nglungger and Medalem with a population of 41,761 people, and a number of families of 10,440 people/family. Kradenan sub-district is geographically located $42 \mathrm{~km}$ from the city of Blora or $162 \mathrm{~km}$ from the provincial capital of Central Java, which borders the province of East Java, namely Ngawi Regency in the south and Bojonegoro Regency in the east [21].

\subsection{Socio-Economic Data}

Types of livelihood according to profile data are $6.1 \%$ employees, $17.39 \%$ entrepreneurs/traders, carpenters, retirees, farmers as farm laborers or farmers who only rent a place/cultivate land belonging to other residents $76.51 \%$. Meanwhile, for the education level the population has on average just finished elementary school.

\subsubsection{Marketing Activities in the Gundih Kradenan Block}

Gas assets in Sumber Village, Kradenan District in 2013 reached 11 sectors with a total connection of 4,000 SRs, sector I consisted of $817 \mathrm{SRs}$, but those that were 
active had only reached 641 SR and the rest had not been flowed, while 10 Sectors had not been energized and had already installed infrastructure / gas network and carried out by the Ministry of Energy and Mineral Resources through the Directorate General of Oil and Gas according to the initial plan, the 4,000 networks are spread in several villages, including Pulo Village, Kemantren Village, Tanjung Village, Kedungtuban District. The hope is that it can complete the 3,359 Jargas household project that has not been flowed in the Central Processing Plan (CPP) area. The responsibility for managing this gas network is left to the State Gas Company (PGN), while the technical implementation of network improvement by PGN is left to its subsidiaries,

\subsubsection{Composition of Natural Gas in the Gundih Kradenan Block}

In conducting simulations for the case study in Sumber Village, Kradenan District, it is necessary to know the composition of the gas being flowed first because this is the first thing that must be done before distributing natural gas. The composition used for the development of this network is the composition of the gas used in the existing network, as presented in Figure 1.

\begin{tabular}{lr}
\hline \multicolumn{2}{c}{ Gas Composition Average $(\%$ Mole $)$} \\
\hline Methana & 93.4867 \\
Nitrogen & 0.4906 \\
CO2 & - \\
Ethane & 34,155 \\
Propane & 12,199 \\
I-Butane & 0.2571 \\
N-Butane & 0.3343 \\
I_Pentane & 0.1336 \\
N_Pentane & 0.1228 \\
N_Hexane & 0.5227 \\
S.G & 0.6118 \\
H.V & $1,094.7371$ \\
\hline
\end{tabular}

Figure 1 Gundih CPP Gas Composition, in Sumber Village

Source: PT PGN Solution Blora-Semarang, September 2019

\subsection{Natural Gas Demand at the Gas Delivery Station in the Central Processing Plant (CPP) Gundih Area}

Gas consumption in 2019 was handed over and flowed by Sumber Village, Kradenan District for the three existing sectors, starting with the Gas Delivery Station in the Central Processing Plant (CPP) in the Gundih Area, for the Blora jargas with mutual agreement for the distribution of natural gas through the natural gas distribution network. For Household Between PT.
Pertamina EP and PT. National gas Company. The distribution of natural gas for CPP Gundih, in Desa Sumber per month is approximately 0.196462 MMCFD / 214,9574 MMBTU. Per year 2.4 MMCFD / 25,794,888 MMBTU. Per 5 years 11.8 MMCFD / 128,974,440 MMBTU. Per 10 Years 117.9 MMCFD / 1,289,744,400 MMCFD, The location of the Gundih CPP for households that are piped in Kradenan Village, Blora Regency. presented as shown Figure 2.

The examples of measuring instruments or gas usage meters who are now using it at the homes of residents of Sumber Village District residents, Kradenan District, Blora

\subsubsection{Gas Flow Capacity}

Gas flow capacity is adjusted to gas requirements. Based on information from PT PGN Solution BloraSemarang, which is on Jalan Peting-Menden Km3, Sumber Village, Kradenan District, the average use of natural gas per household is $15 \mathrm{M} 3$ / month. Based on the field survey conducted, the number of households that will be targeted as natural gas users is 641 households. The total population in Kradenan Subdistrict is 7,364 people with the number of heads of households around 1841 families and those who have utilized the household gas network facilities are 641 families, while 817 have already installed the network but have not had gas, the problem of moving houses, automatically moving buildings because of the village community generally wooden houses), licensing issues from PT KAI. Number of Households that have been supplied with gas: 641 Households. Demand per household $15 \mathrm{M}^{3} /$ month, Total Demand $641 \times 15 \mathrm{M}^{3} /$ month $=9615 \mathrm{M}^{3} /$ month, $(9615 / 30) \times(1495 \mathrm{Kcal}) / 1,000,000: 321 \times(1.495) /$ $1,000,000=0.480$ MSCFD . Total household natural gas needs with a period of time can be calculated per / hour $0.480 \mathrm{M}^{3}$ / hour, $11.517 \mathrm{M}^{3} /$ day, $345.524 \mathrm{M}^{3} /$ month, 4,146,293 M $\mathrm{M}^{3}$ / year, 20,731,464 M3 / 5 years, 41,463 M3 / 10 years Meanwhile, gas needs for households that have a network installed but not yet supplied with gas 817 RT, the total requirement is 0.611 MMSCFD If calculated by the time period, hours $0.611 \mathrm{M} 3$ / hour, 14,657 M3 / day, month 439,707 M3 / month, 5,276,513 $\mathrm{M}^{3}$ / year, $26,382,564 \mathrm{M}^{3} / 5$ years, 52,765,128 $\mathrm{M}^{3} / 10$ years. The calculation is carried out to provide an overview or reference of gas demand according to the estimated age of the gas distribution network project, namely a period of 5 years and 10 years. Natural gas demand in 2019: RT-1, gas demand RT / $\mathrm{M}^{3} / \mathrm{Th}\left(12,255 \mathrm{M}^{3} / \mathrm{bl}\right)=$ 147,060, Rp. 4,250, - / M³ , Rp. 625,005,000,- $\mathrm{M}^{3} /$ year, .RT-2, RT/M $\mathrm{M}^{3}$ /year gas demand $\left(12,255 \mathrm{M}^{3} / \mathrm{bl}\right)=$ 147,060, Rp. 6,600, - / M33, Rp. 970,596,000,- M³/ year, PK-1, RT / $\mathrm{M}^{3} / \mathrm{Th}$ gas demand $\left(12,255 \mathrm{M}^{3} / \mathrm{bl}\right)=$ 147,060, Rp. 4,250, - / M33, Rp. 625,005,000,- $\mathrm{M}^{3} /$ year and PK2, RT / $\mathrm{M}^{3}$ / year gas demand (12,255 $\mathrm{M}^{3} /$ month) $=147,060$, Rp. 6,000, $-/ \mathrm{M}^{3}$, Rp. 882,360,000, $-/ \mathrm{M}^{3}$. 


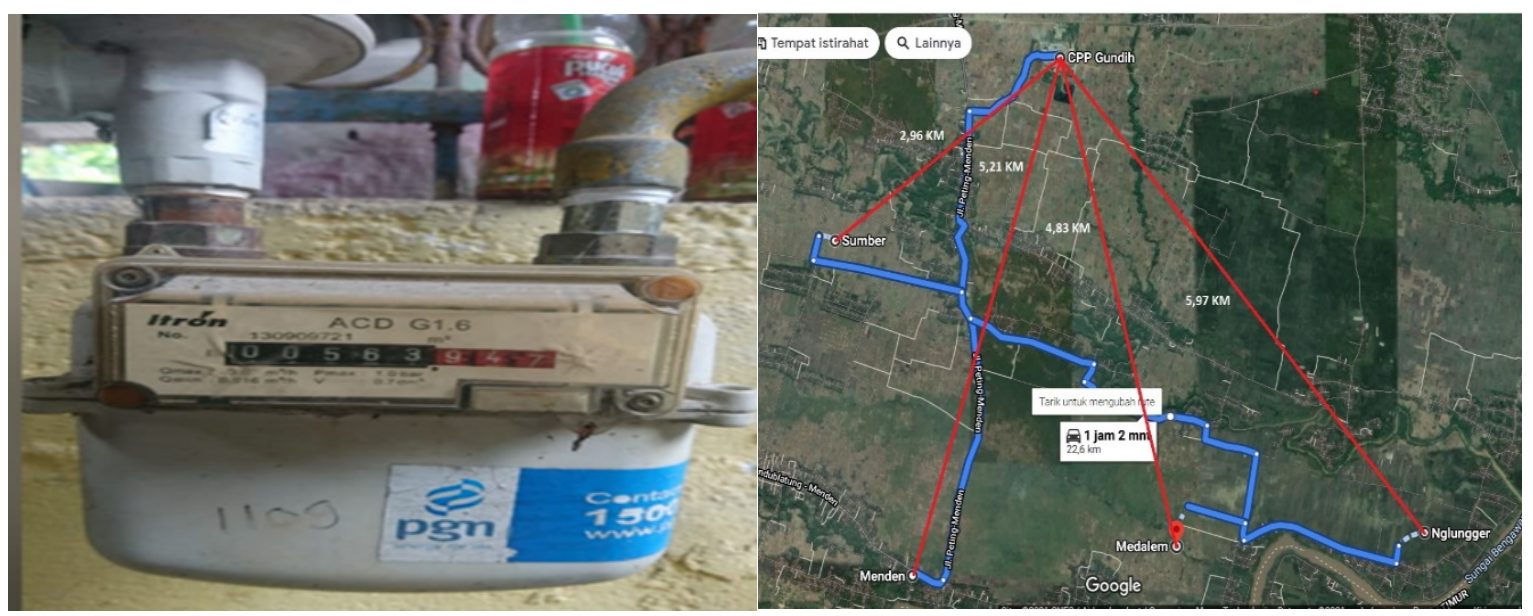

Figure 2 The Location of Gundih CPP and Population and Source: Residents of Kradenan Village

Calculations to determine the amount of peak load, it is assumed that the gas equipment in each household is used simultaneously at the same time and at certain intervals, for example the length of time to use each equipment in one day is 8 hours. Where the assumption used is the number of hours of cooking usage in 1 day is 3 hours, if the total RT Gas Demand is calculated: 9615 $\mathrm{M}^{3} /$ month. and Total Demand for RT Gas $=115,380 \mathrm{M}^{3}$ / year, 1 year 365 days. So that the peak design load for households on the development network is $0.164 \mathrm{M}^{3}$ / hour. Natural gas capacity for RT. with a period of time can be calculated, hours $0.480 \mathrm{~m} 3$ / hour, $11.517 \mathrm{M} 3$ / day, 345.524 $\mathrm{M}^{3}$ / month, 4,146 $\mathrm{M}^{3} /$ year, 20,731 $\mathrm{M}^{3} / 5$ years, $41,463 \mathrm{M}^{3} / 10$ years. It is known that the amount of gas required is $0.164 \mathrm{M}^{3}$ / hour. If it is assumed that the extraction system machine continues to work 24 hours/day for 5 years, 10 years non-stop. Kradenan subdistrict, currently, the selling price of gas with the electricity meter capacity tariff regulation, is R-1/RT1 = Small household consumers with power of $450 \mathrm{VA}$ and $900 \mathrm{VA}$, internal tariff of Rp. 3,333, -, rates according to regulations Rp. 4,250, -, and R-2 / RT2>900 VA, internal rate of $\mathrm{Rp}$. 4,000 , - and the rates according to the regulations is Rp. 6,600, -

\subsubsection{Gas Selling Price in Blora Regency.}

The selling price of natural gas through pipes sold by PT Perusahaan Gas Negara Tbk) for household consumers and small customers in the Blora Regency distribution pipeline network is regulated in the Regulation of the Downstream Oil and Gas Regulatory Agency of the Republic of Indonesia Number 11 of 2018. The level of gas demand that must be supplied from Ds Sumber Field, Kec. Kradenan as many as 641 house connections (SR). Thus, those who have utilized the natural gas network as many as 641 SR in 2019 are 641 $\mathrm{x} 4,146=2,657,774 \mathrm{Scf} / 7,282 \mathrm{scf} /$ day, while the planned natural gas consumption for the Kradenan District SR location is 1,841 households in 2019 of 1841 $\mathrm{x} 4,146=7,633,325$ Scf $/ 20,913$ scf $/$ day. The assumption that there is a loss of 5\%, the gas demand for 1841 houses is 21,959 scf / day / around 0.0220 MMscfd., In addition to the need for households,

Based on the calculation results, the total demand for natural gas in 2019 for 7364 households in Sumber Village, Kradenan District, both those that have been supplied with gas and have installed the network, if the overall need is calculated, it is: $7,364 \times 4,146=$ $30,533,300$ or $83,653 \mathrm{Scf} /$ day or about $0.0837 \mathrm{MMscfd}$

\subsubsection{Calculation of the Cost of Natural Gas Central Processing Plant (CPP) in Sumber Village, Kradenan District}

Central Processing Plant (CPP)in Sumber Village, Kradenan Subdistrict, in determining the cost of products using the cost-of-sale method based on the full costing approach. In determining the cost of goods, there are no raw materials, because only the production process. The cost of the product is determined only in part of the system using activity based costing. The components that appear on the Metering and Regulating Station (MR / S) and Regulating System (RS) are labor costs for the production of the extraction system. The wage / salary for outsourcing workers according to the Central UMR is Rp. $3,648,000$, -. So 4 people / month x Rp. 3,648,000, - = Rp. 14,592,000, -. Office rent in Sumber Village per year Rp. 30,000,000, - / year $=$ Rp. 150,000,000, - / 5 years, then the gas engine produces 24 hours / day too, It is assumed that the gas engine is not problematic and does not shut down as well as the extraction system and will be able to operate for 24 hours ( 720 hours / month).

The cost of electricity is the stage of operation of the distribution pipeline network to households which requires energy of $39,600 \mathrm{Kwh} /$ month. Thus, the electricity cost per Kwh is assumed to be the same as the PLN electricity sales price, which is Rp. 900 / Kwh, so that 39,600 Kwh / month x Rp. $900 /$ Kwh = Rp. $35,640,000$, - fuel costs for transportation, monitor / record in activities used for gasoline Rp. 8000 / liter. So 
60 / liter month x Rp. 8000, - = Rp. 480,000, -, customer management activities, operations such as fuel costs, maintenance Rp. 67,263,943.33, - / year, Rp. 5,605,328.61, - / month, activity monitor extraction machines at power houses - the amount of electricity consumption in these activities is labor costs with electricity costs for operating the blower and chiller machines.

The electricity consumption for this machine is $129,600 \mathrm{kWh} /$ month. So Rp. 129,600 KWh / month x Rp. $900 /$ KWh = Rp. 116,640,000. The cost of equipment and machinery maintenance activities is $7 \%$ per year. The total preparation cost for GPP Gundih which was operating in December 2013 was Rp. 105,204,788,572, and annual maintenance costs of Rp. 105,204,788,572, $\mathrm{x} 7 \%$ / year $=7,364,355,200$, - so that the monthly expenditure becomes Rp. 7,364,355,200, - / 12 months = $613,694,600$, - / month, the monthly expenditure for production extraction system activities is as much as Rp. $1,331,165,595,-$ / month so that the operating cost per year becomes Rp. 1,331,165,595, - / month x 12 months / year $=$ Rp. 15,973,987,140, - / year.

From these costs, it is assumed that each year there is an inflation of $3.5 \%$. It is known that the amount of natural gas output from the extraction system is $0.164 \mathrm{M} 3$ / hour. If it is assumed that the extraction system machine works 24 hours / day for 10 years, then the amount of output that can be produced with a period of time from year to year with an Extraction System gas output capacity of 0.164 M3 / hour, 3,945 M3 / day, 118,356 m3 / month, 1420, $274 \mathrm{M} 3$ / year, 7101,370 m3 / 5 years, 14202,740 M3 / 10 years. Based on the foregoing, the cost of natural gas products is calculated by dividing the total expenditure by the capacity of natural gas produced in accordance with Scenario 2 scenarios, namely a period of 5 years with an expenditure cost of Rp.88,299,848,957, / 5 years, while Rp. $205,960,795,561$, The amount of natural gas capacity in each period of time, namely hours, days, months and years, such as: 1 day $=8,500 \mathrm{M} 3 /$ day, 1 month $=$ $255,000 \mathrm{M} 3$ / day, 1 year $=3,060,000,-\mathrm{M} 3$ / day, 5 years $=15,300,000 \mathrm{M} 3 /$ day 10 years $=30,600,000 \mathrm{M} 3 /$ day.

So that it can be seen that the COGS is in rupiah units per cubic meter for scenario I (5 years), the cost of spending is Rp. 88,299,848,957, - / 5 years, gas demand / capacity $=15,300,000 \mathrm{M} 3$ / 5 years, COGS Rp. 5,771, / M3, while scenario II (10 years), expenditure costs 205,590,795,561, - / 10 years, gas needs / capacity 30,600,000 m3 / 10 years, COGS Rp. 6,731, - / M3. Thus, the total natural gas COGS is determined by adding the COGS of natural gas from the current system, with the proposed COGS. obtained the cost of product that has been calculated for each scenario, as presented in Table 1 :

Table 2. COGS per day for products

\begin{tabular}{lcrrc}
\hline Scenario & Time Period & Gas $/ \mathrm{M}^{3}$ & $\begin{array}{r}\text { Proposal } \\
\text { system }\end{array}$ & Gas requirement capacity \\
\hline Scenario I & $\mathrm{M}^{3} / 5$ year & 5,771 & 8,500 & $49,053,500 \mathrm{M}^{3} /$ day \\
Scenario II & $\mathrm{M}^{3} / 10$ year & 6,731 & 8,500 & $57,213,500 \mathrm{M}^{3} /$ day \\
\hline
\end{tabular}

Referring to Table 1, the COGS per day for each product is obtained as follows. Total COGS $=$ COGS of Natural Gas

$$
\text { COGS (M3) }=\text { Total COGS } / \text { Total Out Put }
$$

Table 3. Total COGS and Natural Gas

\begin{tabular}{lcccr}
\hline \multicolumn{1}{c}{ Scenario } & Total COGS & $\begin{array}{c}\text { Total } \\
\text { COGS/M3/day }\end{array}$ & \multicolumn{2}{c}{$\mathrm{Rp} / \mathrm{M}^{3}$} \\
\hline Scenario I-5 year & Rp49,053,500 & 8,500 & $\mathrm{Rp}$ & 5,771 \\
Scenario II-10 year & Rp57,213,000 & 8,500 & $\mathrm{Rp}$ & 6,731 \\
\hline
\end{tabular}

So, the cost of natural gas products that can be produced by the Central Processing Plant (CPP) in Sumber Village, Kradenan District is scenario I of Rp. $5,771 / \mathrm{M}^{3}$ and scenario II of Rp. 6,731 $\mathrm{M}^{3}$. And Comparative Analysis of Cost of Production Between existing regulations, prices already in effect in Sumber Village, Kradenan District with Researcher's Calculations, with a full costing approach.

Table 4. Comparison of COGS Ds Source with Researchers in scenario I

\begin{tabular}{cllllllr}
\hline \multirow{2}{*}{ Product } & \multicolumn{3}{c}{ COGS Rp/MMBTU } & & \multicolumn{2}{c}{ difference } \\
\cline { 2 - 4 } & \multicolumn{2}{c}{$\begin{array}{c}\text { Internal Sumber Village } \\
\text { of PT PGN }\end{array}$} & \multicolumn{2}{c}{ Researchers /M3 } & & Value & $\%$ \\
\hline \multirow{2}{*}{ natural gas } & $\mathrm{Rp}$ & 3,333 & $\mathrm{Rp}$ & 5,771 & & $2,438.00$ & 1.73 \\
& $\mathrm{Rp}$ & 4,000 & $\mathrm{Rp}$ & 5,771 & & $1,771.00$ & 1.44 \\
\hline
\end{tabular}


Table 5. The comparison of COGS between Regulations and Researchers in scenario I

\begin{tabular}{|c|c|c|c|c|c|c|}
\hline \multirow[b]{2}{*}{ Product } & \multicolumn{4}{|c|}{ COGS Rp/MMBTU } & \multicolumn{2}{|c|}{ difference } \\
\hline & $\begin{array}{r}\text { Reg } \\
\text { Miga }\end{array}$ & $\begin{array}{l}\mathrm{BPH} \\
/ 2018\end{array}$ & Res & $\mathrm{s} / \mathrm{M}^{3}$ & Value & $\%$ \\
\hline \multirow{2}{*}{ natural gas } & $\mathrm{Rp}$ & 4,385 & $\mathrm{Rp}$ & 5,771 & $1,386.00$ & 1.32 \\
\hline & $\mathrm{Rp}$ & 4,250 & $\mathrm{Rp}$ & 5,771 & $1,521.00$ & 1.36 \\
\hline
\end{tabular}

Comparison of HPP Ds Sumber with Researchers from the internal price of PT PGN Solution Blora originally Rp. 3,333, - / $\mathrm{M}^{3}, 4000,-/ \mathrm{M}^{3}$ the cost of re-determination gets a value of Rp. $5771,-/ \mathrm{M}^{3}$, the difference in value of Rp. 2,438, - / $\mathrm{M}^{3}$ (1.73\%). Rp.
1,771, - / $\mathrm{M}^{3}$ (1.44\%), while BPH Migas Regulation No. $11 / 2019$ the price of gas production is $\mathrm{Rp} .4,250 / \mathrm{M}^{3}$, an average of Rp. 4,385, - / $\mathrm{M}^{3}$, with a difference in value $\left(1,386,-/ \mathrm{M}^{3},(1.32 \%), 1.521,-/ \mathrm{M}^{3}(1.36 \%)\right.$.

Table 6. Comparison of COGS Ds Source with Researchers in scenario II

\begin{tabular}{|c|c|c|c|c|c|c|}
\hline \multirow[b]{2}{*}{ Product } & \multicolumn{4}{|c|}{ COGS Rp/MMBTU } & \multicolumn{2}{|c|}{ difference } \\
\hline & \multicolumn{2}{|c|}{$\begin{array}{c}\text { Internal Sumber } \\
\text { Village of PT PGN }\end{array}$} & \multicolumn{2}{|c|}{ Researchers $/ \mathrm{M}^{3}$} & Value & $\%$ \\
\hline \multirow{2}{*}{ natural gas } & $\mathrm{Rp}$ & 3,333 & $\mathrm{Rp}$ & 6,731 & $3,398.00$ & 2.02 \\
\hline & $\mathrm{Rp}$ & 4,000 & $\mathrm{Rp}$ & 6,731 & $2,731.00$ & 1.68 \\
\hline
\end{tabular}

Table 7. The comparison of COGS between Regulations and Researchers in scenario II

\begin{tabular}{|c|c|c|c|c|c|c|}
\hline \multirow[b]{2}{*}{ Product } & \multicolumn{4}{|c|}{ COGS Rp/MMBTU } & \multicolumn{2}{|c|}{ difference } \\
\hline & \multicolumn{2}{|c|}{$\begin{array}{c}\text { Regulation BPH } \\
\text { Migas No: } 11 / 2018\end{array}$} & \multicolumn{2}{|c|}{ Res earchers $/ \mathrm{M}^{3}$} & \multirow{2}{*}{$\begin{array}{l}\text { Value } \\
2,346.00\end{array}$} & \multirow{2}{*}{$\frac{\%}{1.54}$} \\
\hline & $\mathrm{Rp}$ & 4,385 & $\mathrm{Rp}$ & 6,731 & & \\
\hline natura & $\mathrm{Rp}$ & 4,250 & $\mathrm{Rp}$ & 6,731 & $2,481.00$ & 1.58 \\
\hline
\end{tabular}

The price of PT PGN Solution Blora's internal gas products was originally priced at Rp. 3,333, - / $\mathrm{M}^{3}$ and the researcher's calculation of Rp. $6,731,-/ \mathrm{M}^{3}$ - there is a difference of Rp. 3,398, - / $\mathrm{M}^{3}$, around $2.02 \%$, and the price of PT PGN Solution Blora, the price of gas production is Rp. 4,000, - / M3, the researchers calculated Rp. $6,731,-/ \mathrm{M}^{3}$ there is a difference of Rp. 2,731, - / $\mathrm{M}^{3}$ is around $1.68 \%$, while the cost of goods sold is in accordance with BPH Migas Regulation No. 11/2018, the price of gas production is Rp. 4,385, - / M3 and the researcher's calculation of $\mathrm{Rp} .6,731,-/ \mathrm{M}^{3}$, there is a difference of Rp. 2,346, - / M3 around 1.54\%, and the cost of enforcing BPH Migas Regulation No. 11/2018 the price of gas production is Rp. $4.250,-/ \mathrm{M}^{3}$, - and the researcher calculation of Rp. 6,731, - / $\mathrm{M}^{3}$, there is a difference of Rp. 2,481, - / $\mathrm{M}^{3}$, about $1.58 \%$

It shows that the calculation of the cost of products using the method already regulated in BPH Migas Regulation Number: 11/2018 dated 27 November 2018 results in a higher cost of goods manufactured for natural gas.

The Selling prices according to the company and according to the Cost Plus Pricing Method per $1 \mathrm{M}^{3}$ of natural gas in Scenario I and Scenario II are:

Table 8. Comparison of COGS Ds Source with Researchers in scenario I

\begin{tabular}{|c|c|c|c|c|c|c|}
\hline \multirow[b]{2}{*}{ Product } & \multicolumn{4}{|c|}{ COGS Rp/MMBTU } & \multicolumn{2}{|c|}{ difference } \\
\hline & \multicolumn{2}{|c|}{$\begin{array}{l}\text { Internal Sumber } \\
\text { Village of PT PGN }\end{array}$} & \multicolumn{2}{|c|}{ Res earchers $/ \mathrm{M}^{3}$} & Value & $\%$ \\
\hline \multirow{2}{*}{ natural gas } & $\mathrm{Rp}$ & 3,333 & $\mathrm{Rp}$ & 6,638 & $3,305.00$ & 1.99 \\
\hline & $\mathrm{Rp}$ & 4,000 & $\mathrm{Rp}$ & 6,638 & $2,638.00$ & 1.66 \\
\hline
\end{tabular}


Table 9. The comparison of COGS between Regulations and Researchers in scenario I

\begin{tabular}{|c|c|c|c|c|c|c|}
\hline \multirow[b]{2}{*}{ Product } & \multicolumn{4}{|c|}{ COGS Rp/MMBTU } & \multicolumn{2}{|c|}{ difference } \\
\hline & $\begin{array}{r}\mathrm{Re} \\
\mathrm{Mig} \\
\end{array}$ & $\begin{array}{l}\mathrm{PH} \\
2018 \\
\end{array}$ & Res & $s / M^{3}$ & Value & $\%$ \\
\hline \multirow{2}{*}{ natural gas } & $\mathrm{Rp}$ & 4,385 & $\mathrm{Rp}$ & 6,638 & $2,253.00$ & 1.51 \\
\hline & $\mathrm{Rp}$ & 4,250 & $\mathrm{Rp}$ & 6,638 & $2,388.00$ & 1.56 \\
\hline
\end{tabular}

Table 10. Comparison of COGS Ds Source with Researchers in scenario II

\begin{tabular}{|c|c|c|c|c|c|c|}
\hline \multirow[b]{2}{*}{ Product } & \multicolumn{4}{|c|}{ COGS Rp/MMBTU } & \multicolumn{2}{|c|}{ difference } \\
\hline & \multicolumn{2}{|c|}{$\begin{array}{c}\text { Internal Sumber } \\
\text { Village of PT PGN }\end{array}$} & \multicolumn{2}{|c|}{ Researchers $/ \mathrm{M}^{3}$} & Volue & $\%$ \\
\hline \multirow{2}{*}{ natural gas } & $\mathrm{Rp}$ & 3,333 & $\mathrm{Rp}$ & 7,741 & $4,408.00$ & 2.32 \\
\hline & $\mathrm{Rp}$ & 4,000 & $\mathrm{Rp}$ & 7,741 & $3,741.00$ & 1.94 \\
\hline
\end{tabular}

Table 11. The comparison of COGS between Regulations and Researchers in scenario II

\begin{tabular}{|c|c|c|c|c|c|c|}
\hline \multirow[b]{2}{*}{ Product } & \multicolumn{4}{|c|}{ COGS Rp/MMBTU } & \multicolumn{2}{|c|}{ difference } \\
\hline & \multicolumn{2}{|c|}{$\begin{array}{c}\text { Regulation BPH Migas } \\
\text { No: } 11 / 2018\end{array}$} & \multicolumn{2}{|c|}{ Researchers $/ \mathrm{M}^{3}$} & Volue & $\%$ \\
\hline \multirow{2}{*}{ natural gas } & $\mathrm{Rp}$ & 4,385 & $\mathrm{Rp}$ & 7,741 & $3,356.00$ & 1.77 \\
\hline & $\mathrm{Rp}$ & 4,250 & $\mathrm{Rp}$ & 7,741 & $3,491.00$ & 1.82 \\
\hline
\end{tabular}

The selling price according to the company and according to the Cost Plus Pricing Method per $1 \mathrm{M}^{3}$ of natural gas in Scenario I and Scenario II is the level of efficiency. According to the Cost Plus Pricing method per $1 \mathrm{M}^{3}$ natural gas in scenario I is Rp. 6,638, - / $\mathrm{M}^{3}$, the difference is Rp. 3,305, - / $\mathrm{M}^{3}$ (1.99\%), Rp. 2,638, - / $\mathrm{M}^{3}$ (1.66\%), while the second scenario is Rp. $7,741,-/ \mathrm{M}^{3}$ difference of Rp. 4,408, - / $\mathrm{M}^{3}$ (2.32\%). Rp. 3,741, - / $\mathrm{M}^{3}$ (1.94\%), Rp. 3,356, - / $\mathrm{M}^{3}$ (1.77\%), Rp. 3,491, - / $\mathrm{M}^{3}$ $(1.82 \%)$.

\section{CONCLUSION}

The results of the calculation of the cost of gas with the production of gas at CPP Gundih for Scenario I, from the internal price of PT PGN Solution Blora and the determination of the cost of natural gas based on recalculation by researchers, the natural gas that can be produced by the Central Processing Plant (CPP) scenario I is Rp. 5,771/ $\mathrm{M}^{3}$ is the difference of Rp. 1,521/ $\mathrm{M}^{3}$ $(1.36 \%)$, and the second scenario is Rp. $6,731 \mathrm{M}^{3}$. with a difference of Rp. $2,481 / \mathrm{M}^{3}$ (1.58\%) and the calculation of COGS in accordance with the regulations according to the calculation of the researcher resulted in a higher cost of goods because the natural gas marketed in Sumber Village, Kecamatan, was lower than what the government had set.

Determination of the selling price at the company with the cost plus pricing approach with the full costing approach experiences differences. The selling price of the internal gas product price of PT PGN Solution Blora, according to BPH Migas Regulation No.11/2019 and the price of restating it to the gas production price according to the Cost Plus Pricing method per $1 \mathrm{M}^{3}$ natural gas scenario I of Rp. 6,638, - / $\mathrm{M}^{3}$ the difference is Rp. 2,387, - / $\mathrm{M}^{3}(1.56 \%)$ while the second scenario is Rp. 7,741, the difference of Rp. 3,491, - / $\mathrm{M}^{3}$ (1.82\%). The cost plus pricing method uses the cost factor as the basis for calculating it, so it must be recorded all the costs required during the production process. If this continues, especially in the industrial and electricity sector, the gas sub-holding company (PGN) that carries out the implementation of government assignments will suffer losses.

\section{ACKNOWLEDGMENTS}

Thank you to the Director of the Dharma Patria Polytechnic who has allowed research on campus and students who have helped.

\section{REFERENCES}

[1] Jerry J. Weygandt, Donald E. Kieso, Paul D. Kimmel. Introduction to Accounting (Seven Edition). Jakarta: Four Salemba. 2013.

[2] [2016, Maret, 31]. "Perbandingan Kalkulasi Biaya Penggunaan", [online]. Available: komporinduksi.blogspot.com. 
[3] Energy Measurements and Conversions, PT Pertamina, 2018

[4] Astanti, Vera. (2017, Mei 5) Perawatan Sumur Gundih Pertamina Ep Asset 4 [online]. Available: beritabojonegoro.com

[5] Pertiwiningrum Ambar, Instalasi Biogas, Penerbit CV Kolom Cetak, ISBN: 978-602-749-290-5, Cetakan I, Agustus 2016.

[6] Lestari, Maria Puji, Penentuan Harga Pokok Energi Listrik Pada PT. PLN (Persero) Wilayah Suluttenggo Manado, Universitas Sam Ratulangi Manado, Jurnal EMBA. 2013

[7] Srilarakasuri P Ardiagarini, Anthony Riman, Helena J Kristina, Perhitungan Harga Pokok Produk Compressed Natural Gas Dari Landfill Gas Sebagai Energi Alternatif Pada Tpst Bantar Gebang, Bekasi, Jurusan Teknik Industri, Universitas Pelita Harapan-Tangerang, J@TI Undip, Vol VIII, No 2, Mei 2013

[8] Buku Jargas, Direktorat Jenderal Minyak dan Gas Bumi, Kementerian Energi dan Sumber Daya Mineral, Pembangunan Jaringan gas bumi untuk pemerintah, migas.esdm.go, 2013

[9] Tahar, Arcandra, (2018, Oktober, 1) "NERACA GAS INDONESIA 2018-2027”' [online]. Available esdm.go.id

[10] ---------, (2008, October). Energy Measurements and Conversions, [online] File C6-86. Available: www.extension.iastate.edu/agdm.

[11] -------------, Peraturan Badan Pengatur Hilir Minyak Dan Gas Bumi tentang Pedoman Penetapan Harga Gas Bumi Untuk Rumah Tangga Dan Pelanggan Kecil, Nomor : 03/P/BPH Migas/I/2005, Tahun 2005
[12] ----------------, Peraturan Menteri ESDM Tentang Ketentuan dan Tata Cara Penetapan Alokasi dan Pemanfaatan serta Harga Gas alam, No. 6 Tahun 2016 Jakarta, Kementerian Energi dan Sumber Daya Mneral

[13] -------------, Indonesia, Peraturan Menteri ESDM Tentang Harga Gas alam untuk Industri Tertentu, No. 40 tahun 2016

[14] Republik Indonesia, 2014, Peraturan Pemerintah No. 79 Tahun 2014 Tentang Kebijakan Energi Nasional,

[15] Republik Indonesia, Peraturan Presiden No. 40 Tahun 2016 Tentang Penetapan Harga Gas alam.

[16] Peraturan BPH Migas tentang Nomor: 11 tahun 2018 Tgl.27 November 2018 tentang harga jual gas bumi melalui pioa untuk konsumen Rumah Tangga dan pelanggan kecil pada jaringan pipa distribusi Kabupaten Blora.

[17] Peraturan Gubernur DKI Jakarta nomor 114 Tahun 2018.

[18] Pernyataan Standar Akuntansi Keuangan (PSAK ) Nomor 29: Akuntansi Minyak dan Gas alam.

[19] Pusat Data dan Teknologi Informasi Energi dan sumber Daya Mineral tentang Kajian Subtitusi Gas dengan energi lain pada sektor Industri, Tahun 2013.

[20] BPS, Bappenas dan Kemenkeu, Asumsi Dasar Ekonomi Makor APBN2019

[21] Dinas Kependudukan dan Pencatatan Sipil, 2019, Profil Kependudukan dan Pencatatan Sipil Kabupaten Blora . 